\title{
How Do Business And Government Interact? Combining Perspectives From Economics, Political Science, Public Administration, And Practitioners
}

Patrick B. O’Neill, University of North Dakota, USA

Dana Michael Harsell, University of North Dakota, USA

\begin{abstract}
The authors describe the theoretical preparation provided to students in advance of a limitedduration experiential learning experience in Washington DC in a Master's level course for students in Business or Public Administration. The students consider theoretical perspectives from economics, political science, and public administration with respect to the interactions of business and government in the US economy. The students field test the theories via meetings with practitioners in Washington DC and are required to reflect on and then apply how reality does (or does not) map into theory.
\end{abstract}

Keywords: Experiential Learning; Role Of Government In Markets; Government And Business Interactions; The Role Of Lobbying In The US Economy

\section{INTRODUCTION}

In an earlier paper (Harsell and O'Neill, 2010), the authors described logistical lessons associated with an experiential learning course consisting of an in-depth experience in Washington DC for MBA and MPA students. That paper also discussed the "practical preparation" of the students to ensure for a successful field experience. In this companion paper, the authors present a description of the classroom activity that focused on the theoretical background to prepare the students for the DC experience, as well as the follow-up class sessions, wherein students were asked to compare the theory with the reality of their field experience in DC.

\section{THEORETICAL BACKGROUND - AN ECONOMICS PERSPECTIVE}

The authors begin the orientation of the students to the relationship between business and government by presenting some basic perspectives from the discipline of economics, from both a macroeconomics and a microeconomics perspective.

\section{Government and Business - A Macroeconomics View}

The starting point is the introduction of two dichotomies - capitalism versus socialism and Keynes versus Hayek. The main vehicle used for this is the PBS documentary The Commanding Heights based on the book of the same title (Yergin and Stanislaw, 2002). In earlier years, students viewed the first two hours of the six-hour documentary. More recently, the authors have settled on snippets of the documentary. In either form, the relevant question is, "Who controls the commanding heights of the economy - business or government?" The documentary focuses on the US, Great Britain and the Soviet Union from the industrial revolution to the early 2000 s and compares capitalism and socialism, along with the views of Keynes and Hayek. Some humor is interjected via the Keynes v Hayek rap video entitled "Fear the Boom and Bust" (Econ Stories, 2010). The authors provide additional background information for the students on Keynes v Hayek and have them write a position paper describing which 
economist's views most resonates with their own. (The course handout containing the list of additional sources is in the Appendix to this paper.) This is discussed in class and leads to lively debates.

\section{Government and Business - A Microeconomics View}

A microeconomics presentation of government and business takes two forms: (1) the role of government in markets and (2) how government impacts the decisions of individual firms.

\section{Markets}

The class explores the role of markets in economies - over time and place - using the book Reinventing the Bazaar (McMillan, 2002) as the main vehicle for facilitating discussion. McMillan (pp ix-x) lists five elements needed for workable markets:

1. Information flows smoothly

2. $\quad$ Property rights are protected

3. People can be trusted to live up to their promises

4. Side effects on third parties are curtailed

5. Competition is fostered

These five elements form the basis for moving students toward the possibility of viewing government and business as partners, rather than as adversaries, in a functioning economy, as the role of government in providing/securing these elements is discussed.

Firms - Equations

The final segment of the standard economics discussion involves a brief treatment of the standard microeconomic theory of the firm. This theory considers firms to have a single goal of profit maximization that can be expressed via the following equation:

$\operatorname{Max} \Pi(Q)=R(Q)-C(Q)$

$\mathrm{Q}>0$

where $\Pi$ is profit, $R$ is revenue, $C$ is cost, and $Q$ is output.

First order conditions from this optimization problem yield the familiar economic result:

$\mathrm{R}^{\prime}(\mathrm{Q})-\mathrm{C}^{\prime}(\mathrm{Q})=0$

$\mathrm{R}^{\prime}(\mathrm{Q})=\mathrm{C}^{\prime}(\mathrm{Q})$ or $\mathrm{MR}=\mathrm{MC}$

That is, the firm will maximize profit by choosing its level of output where marginal revenue equals marginal cost.

The authors next propose an alternative view (derived from the dozen years of teaching the course) which requires the students to re-orient their thinking and consider government as a strategic partner. The idea is that the firms should consider spending resources (via lobbying, et al.) to influence the market mechanisms in their industry. Examples of successful influence include subsidies for wind power generation, prevention of restrictions on the sale of large size non-alcoholic beverages in New York, etc. In terms of the formal presentation, this changes the objective function by adding government as a second decision variable:

$\operatorname{Max} \Pi(\mathrm{Q}, \mathrm{G})=\mathrm{R}(\mathrm{Q}, \mathrm{G})-\mathrm{C}(\mathrm{Q}, \mathrm{G})$

$\mathrm{Q}, \mathrm{G}>0$

where $\Pi$ is profit, $R$ is revenue, $C$ is cost, $Q$ is output, and $\mathrm{G}$ is expenditures on government influence activities. 
First order conditions yield the following result:

$\mathrm{R}^{\prime}(\mathrm{Q})-\mathrm{C}^{\prime}(\mathrm{Q})=0$

$\mathrm{R}^{\prime}(\mathrm{Q})=\mathrm{C}^{\prime}(\mathrm{Q})$

$\mathrm{R}^{\prime}(\mathrm{G})-\mathrm{C}^{\prime}(\mathrm{G})=0$

$\mathrm{R}^{\prime}(\mathrm{G})=\mathrm{C}^{\prime}(\mathrm{G})$

That is, pick both $\mathrm{Q}$ and $\mathrm{G}$ where the marginal revenue from either choice variable equals the marginal cost of that choice variable.

Firms - Diagrams

A less formal way to present these two views is via simple diagrams. In the standard microeconomic theory perspective [equation (1) above], government is typically characterized as a constraint on the firm's ability to generate a profit. Examples include such factors as carbon emission reduction expenses for electric utilities, compliance activities of banks, etc., as illustrated in Figure 1.

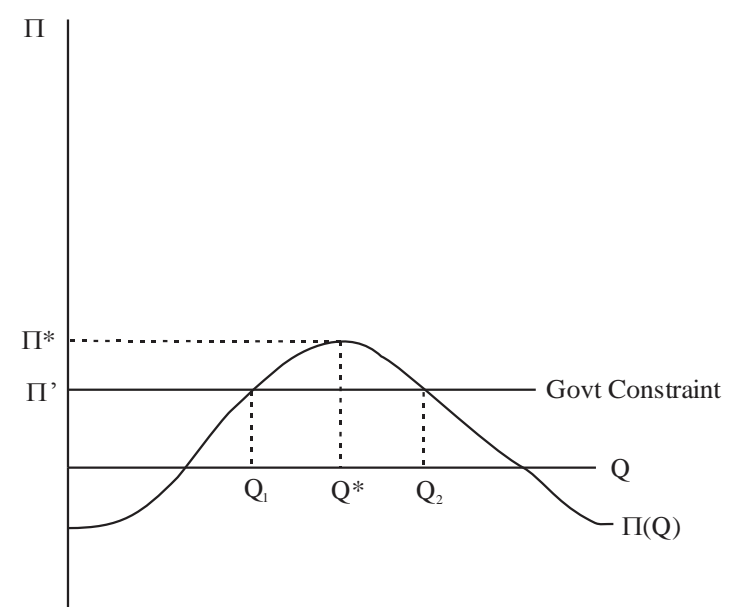

Figure 1: Standard Theory View- Profit With And Without Government As A Constraint On Firm Choice

Without government activity, the firm produces $\mathrm{Q}^{*}$ and earns maximum profit of $\Pi^{*}$. With government activity, the firm produces either $\mathrm{Q}_{1}$ or $\mathrm{Q}_{2}$ and earns $\Pi^{\prime}<\Pi^{*}$.

Turning to the proposed alternative perspective [equation (2) above], this can be illustrated as an attempt by the firm to change the profit function so as to generate additional profit for the same output produced. This is illustrated in Figure 2. 


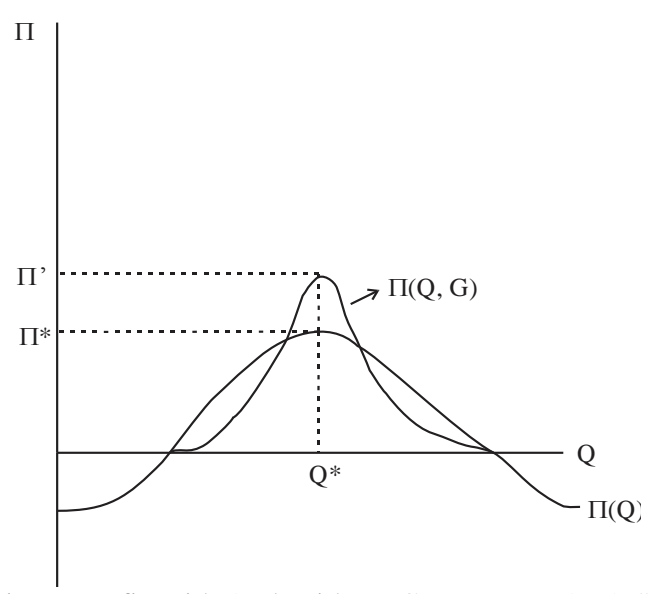

Figure 2: Alternative View - Profit With And Without Government As A Strategic Choice Variable

Here, the firm produces $Q^{*}$ as in the non-constrained (no government activity) case as in Figure 1, but earns more profit: $\Pi^{\prime}>\Pi^{*}$.

The above diagrams provide an illustration of the perspective on the relationship between business and government that the authors want students to take away from the course. The authors want students to realize that by viewing government as a strategic variable, business has the opportunity to reshape its profit function (Figure 2) and thus actually increase overall profit, rather than view government as an adversary which restricts profit (Figure 1). To foster this alternative view, the students are provided background material related to the nature of influencing government, in theory, as well as how that influence is exhibited during the field experience in DC. Both topics are presented next.

\section{Theoretical Background - A Political Science Perspective}

The students are next introduced to a discussion of how individuals or groups (including businesses) in society interact with government, from the perspective of political science and public administration. A main focus of the presentation involves a discussion of the nature of lobbying as a means for interaction with the government, utilizing the book The Interest Group Society by Berry and Wilcox [BW] (2009).

The BW discussion begins with a conversation about how individuals begin to coalesce their support around political issues. At some point, these groups may begin to lobby government officials to address their wants or needs. The porousness of the American political system grants any interested individuals and groups a multitude of access points to influence legislation from formulation to implementation. It is worth noting that within the system of checks and balances, interested parties and individuals can seek action or redress from the legislature, the executive or the courts. Within the system of federalism, interested parties can seek change from federal, state and sub-state levels of government.

This access can be enhanced by the pluralist nature of the American political context. Pluralists hold that virtually everyone in society is represented by some organized group that acts on their behalf. The porousness of American political system provides access to interested groups and individuals, but also works to temper their influence. In Federalist \#10, James Madison (1787) proposed that a large, representative form of government would ultimately serve to insulate society from the negative effects of factions (i.e., interest groups) by pitting these interests against one another and balancing them out.

Once students understand the political context that interest groups and lobbyists operate in, the discussion turns toward their activities. To this end, students learn about different kinds of lobbies and interest groups and the strategies they use to engage government in all branches and levels. The class examines the demographics and professional backgrounds of lobbyists and learns about legal restrictions on their behavior and that the profession promulgates a code of ethics for lobbyists to adhere to. In essence, interest groups, lobbyists and the act of lobbying government serve as an important link between governance and society. 


\section{Toward A Synthesis - Economics Meets Political Science And A Business Strategy Is Born}

Combining the concept of lobbying with the proposition that firms need to consider government as a strategic player, the students read a management book that takes this viewpoint - Winning the Influence Game by Watkins, Edwards, and Thakrar [WET] (2001).

In WET, the discussion becomes business-focused and strategic. The bottom line from the book is that if a business is not actively involved in influencing government to its advantage, its competitors will be - and that will be disadvantageous. WET is filled with examples and lists of things to do (and not to do) when organizing an influence campaign. There are several important lists provided in the book, all related to advice on how to win the influence game summarized as follows:

1. Seven Fundamental Principles for influencing rule making culled from interviews of Washington lobbyists, Government relations professionals and government officials (WET, Chapter 1)

2. Fifteen tips related to the importance of building and maintaining relationships (WET, Chapter 4)

3. Ten Techniques for Coalition Building (WET, Chapter 6)

4. $\quad$ Five Pitfalls to Avoid When Coalition Building (WET, Chapter 6)

5. Seven Rules of Issue Framing (WET, Chapter 7)

The material in WET can be distilled to three key points:

1. Key\#1 Relationships - who you know and who you can connect with whom

2. Key \#2 Shape the Agenda - frame the issue so it is presented from your perspective

3. Key \#3 Tell the truth - misrepresenting information guarantees failure - so don't

\section{Theory Meets Practice - Students Visit Washington DC}

In transitioning from theory to practice, students encounter (1) government and business actually working as partners, (2) the importance of lobbying, and (3) pluralism in action.

\section{Government And Business As Partners}

The public sector has historically had a significant relationship with the private sector, although this is tempered by the founding-era "cultural expectation of minimal interference" in private affairs (see Box 1999, p. 20). Although the modern era has also been marked by growing acceptance for government to promote business interests and maintain the economy, students are often surprised to learn first-hand how entwined these two sectors have become. McMillan writes that "in a well-functioning economy, the state is quietly helping to ensure that productmarket competition continues to exist and that financial markets are working properly" (2002, p. 175). Two of the agencies visited during the trip have strong interactions with private markets, the Department of Commerce and the General Services Administration (GSA).

The Commerce Department's mission emphasizes “job creation, economic growth, sustainable development and improved standards of living for all Americans by working in partnership with businesses, universities, communities and our nation's workers" (2014) and oversees a myriad of other programs that operate at the state, federal and local levels to promote business and international and domestic trade. As part of its mission to "deliver the best value in real estate, acquisition, and technology services to government and the American people" (U.S. General Services Administration [GSA], 2014), the GSA often works closely with private sector entities.

\section{The Importance Of Lobbying}

Whether businesses view government as a strategic variable to be managed (WET view) or as a partner (McMillan view), a central part of either view is the activity of lobbying. Indeed, lobbyists perform a crucial role of information dissemination. Students are often surprised to hear lessons from the texts and lectures repeated or affirmed in various ways during the discussion with Washington practitioners. For example, BW (2009) offer five 
"unwritten rules" that effective lobbyists follow (pp. 103-107). First, and perhaps most important, is that "credibility comes first" (p. 103). Often, lawmakers depend on lobbyists to provide data or information about legislative issues; speakers consistently reinforce that their reputation "is everything" and that misleading an elected official or their staff would mean an abrupt end to their relationship and probably their ability to conduct their business at all (Consistent with Key \#3 from WET above). This ethic of trust is so engrained within the speakers that they stated they have even shared information with lawmakers or government officials that is not necessarily favorable to their own position on an issue.

Another example relates to WET (2001) wherein, as noted above, the authors present seven "rules of framing" (pp. 181-187) to demonstrate the importance of managing the perspective within which an issue is discussed. In public discourse, complex policy issues are often distilled into two or more competing frames. One of the DC speakers is fond of pointing out that success often comes to the group that crafts and presents the most resonate frame to policy makers and the public. An illustrative case concerns pharmacy ownership in the state of North Dakota. Since 1963, "North Dakota's Pharmacy Ownership Law stipulates that only pharmacies that are majority owned by a licensed pharmacist (or a group of pharmacists) may be granted permission to operate in the state" (Institute for Local Self-Reliance, 2014). This law prevents corporations (such as Wal-Mart or Target) from owning and operating pharmacies in North Dakota. In 2009, the state legislature defeated a proposal to repeal this law. The repeal campaign was "financed and led primarily by Wal-Mart and Walgreen's" (Institute for Local SelfReliance, 2014). The pro-repeal message asserted that allowing national pharmacy chains into North Dakota would result in lower prescription prices, since the larger pharmacies could pass on savings realized from economies of scale in purchasing of medicine from suppliers. The anti-repeal message (presented in class by a student working for a local advertising agency involved in the effort) maintained that allowing corporate pharmacies to operate in North Dakota would drive many of the "mom-and-pop" pharmacies in small towns out of business and thus jeopardize the ability of residents in many ND communities to even get prescriptions, regardless of the price. The repeal effort "failed by a vote of 34-57 in the House of Representatives" (Institute for Local Self-Reliance, 2014). In a similar vein, students often hear about the importance of "managing the message" during the DC experience. Frames are ephemeral and the DC speakers (and other members of the interests or firms they represent) are well-prepared to defend their issue positions and frames with data and research. To the extent that private organizations can offer expertise or other resources to lawmakers and regulators, they can have a hand in shaping the legal and regulatory environments where they conduct business (WET, 2001).

\section{Pluralism In Action}

The concept of American pluralism is reinforced by visits to trade associations, business lobbyists, government relations staff, and federal agencies, as well as visits with lawmakers and their staff. Through these visits, students learn how a myriad of groups, interests and issues are represented. They also learn how important this representation is from both a government and business perspective. To this end, one of the DC practitioners is fond of telling a story about her incredulity when she met a lobbyist representing the Corporate Libraries of America early in her career. When the practitioner asked why libraries would need a lobbyist, she was told, "everyone needs representation in Washington." Her story further underscores a point made by WET (2001) - those who do not engage in the "influence game" may find themselves in a competitive disadvantage.

\section{Closing The Loop - Students Reflect On And Apply What They Have Experienced}

An important component of any experiential learning experience includes "closing the loop" by allowing students time to reflect on their experience, to connect these experiences to theory, and then apply what they have learned. Post trip assignments have generally taken two forms. The first form constitutes a reflective essay, where students are asked to identify examples from the texts and lectures and reflect on the extent to which these were or were not consistent with their DC trip experience. Other reflective assignments have varied but have included asking students to write a memo or letter to future students detailing their trip experience, as well as providing an outline for an "introductory book chapter" that could be used in the course. The second form of assignment asked students to apply what they learned from the class to a specific policy issue. These have manifested in oral presentations that take the form of a Congressional committee hearing, producing a "press-kit" of a specific issue and, more recently, a paper that provides an issue briefing (written from the perspectives of either a Legislative Affairs staffer in Congress 
or an Executive for General Motors) for the National Highway Traffic Safety Administration (NHTSA) ordered recall of Chevy Cobalt cars to replace faulty ignition switches. For a complete example (including instructions to the students), see the Appendix to Harsell and O’Neill (2010, p 33).

\section{CONCLUSION}

This paper presents details of the background material provided to students in a combined MBA/MPA course about the nature of the relationship between government and business. The authors present a theoretical introduction to this topic by providing perspectives from economics, political science, and public administration. Students evaluate the various theoretical approaches via a field experience in Washington DC. Students discover that theory maps very well into reality and leave the course with a new appreciation for the importance of business and government working together in order to make the economy prosper.

\section{AUTHOR INFORMATION}

Patrick B. O'Neill is Associate Dean for Administration and Professor and Clow Memorial Fellow in the Department of Economics at the University of North Dakota. He teaches courses in principles of macroeconomics, microeconomic theory, and managerial economics. He holds a BA in economics from the University of St. Thomas (St. Paul, MN) and an MA and PhD from Boston College. His research interests include the teaching of economics, the theory of the firm, and the intersection of economics and ethics. Email: poneill@business.und.edu.

Dana Michael Harsell is Associate Professor and MPA Director in the Department of Political Science and Public Administration at the University of North Dakota. He teaches courses in state and local government, public administration and public management. Dr. Harsell holds a BA in political science and psychology and an MA in political science, both from the University of Montana, and a $\mathrm{PhD}$ in political science from Syracuse University. Dana's research interests include public management and performance, public service provision and arts and culture policy. Email: dharsell@business.und.edu.

\section{REFERENCES}

Berry, Jeffrey M., \& Wilcox, Clyde. (2009). The interest group society, 5e, New York: Pearson.

Box, Richard C. (1999). Running government like a business: Implications for public administration theory and practice. American Review of Public Administration, 29, 19-43.

Fear the Boom and Bust. (2010), EconStories, Retrieved from http://econstories.tv/fear-the-boom-and-bust/.

Harsell, D.M. \& O'Neill. (2010). Experiential learning: lessons learned from the UND Business and Government Symposium. American Journal of Business Education, 3:8, 27-33.

Institute for Local Self-Reliance. (2014). Pharmacy ownership law - North Dakota. Retrieved from http://www.ilsr.org/rule/pharmacy-ownership-laws/2832-2/.

Madison, James. (1787). Federalist \# 10. In, Clinton Rossiter (Ed.), The Federalist papers (pp. 77-91). New York: Mentor.

McMillan, John. (2002). Reinventing the bazaar: A natural history of markets, New York: W. W. Norton.

US Department of Commerce. (2014). Mission statement. Retreived from: http://www.commerce.gov/aboutdepartment-commerce.

US General Services Administration. (2014). Mission. Retrieved from: http://www.gsa.gov/portal/content/104774.

Watkins, M., Edwards, M., \& Thakrar, U.. (2001). Winning the influence game: What every business leader should know about government, New York: Wiley.

Yergin, D., \& Stanislaw, J. (2002). The commanding heights: The battle for the world economy, New York: Free Press. 


\section{APPENDIX}

Additional sources for Keynes and Hayek

Who should control the commanding heights?

I. PBS Documentary based on the book The Commanding Heights

http://www.pbs.org/wgbh/commandingheights/lo/index.html

Direct link to the videos viewed in class: http://www.pbs.org/wgbh/commandingheights/lo/ideas/vid essaylist.html

II. Hayek v Keynes Fun Videos

Video 1: http://econstories.tv/fear-the-boom-and-bust/

Video 2: http://econstories.tv/fight-of-the-century/

III. Some additional information from The Concise Encyclopedia of Economics edited by David R. Henderson. Specific titles to investigate include (but need not be limited to):

- $\quad$ Austrian School of Economics by Peter J. Boettke

- $\quad$ Government Growth by Robert Higgs

- $\quad$ Keynesian Economics by Alan S. Blinder

- $\quad$ Along with biographies of John Maynard Keynes and Friedrich August Hayek

NOTE: You may find a hard copy of The Concise Encyclopedia of Economics at the Chester Fritz Library reference section or online at http://www.econlib.org/library/CEETitles.html

IV. Some books

Yergin and Stanislaw The Commanding Heights

http://www.amazon.com/Commanding-Heights-Battle-World-

Economy/dp/068483569X/ref=sr_1_1?s=books\&ie=UTF8\&qid=1356638732\&sr=1-

$1 \&$ keywords=the+commanding+heights

Nicholas Wapshott Keynes Hayek: The Clash that Defined Modern Economics

http://www.amazon.com/Keynes-Hayek-Defined-Modern-

Economics/dp/0393343634/ref=sr_1_2?s=books\&ie=UTF8\&qid=1356638785\&sr=1-2\&keywords=keynes 